\title{
ANALYSIS OF POSSIBLE WAYS FOR UKRAINE TO ENTER THE INTERNATIONAL SCENE OF EARTH REMOTE SENSING
}

\author{
Institute of Technical Mechanics \\ of the National Academy of Sciences of Ukraine and the State Space Agency of Ukraine \\ 15 Leshko-Popel St., 49005,Dnipro,Ukraine; e-mail: pkorol@ukr.net
}

The aim of this paper is to analyze possible ways of using images from Ukrainian Erath remote sensing satellites which would allow Ukraine to enter the international scene with participation in international projects.

At present, the use of satellite images shows a rapid development. All over the world, new, nontraditional for Earth remote sensing customers, such as banks, insurance companies, large distribution networks, etc., have begun to realize the opportunities and benefits of using geoinformational technologies and space monitoring. The world trend is towards a full multiple cover of the whole of the Earth surface with a high spatial resolution during a year. Technologically, the key operators of Earth remote sensing space systems are already ready for this. Ukraine has not yet positioned itself as a country that could participate in satellite imagery, although the availability of Earth remote sensing satellites is declared in conceptual documents:

- the Concept of the State Policy of Ukraine in Space Activities up to 2032 declares a stationary constellation of Earth remote sensing satellites;

- the Draft State Target Scientific and Technical Space Program of Ukraine envisages the launch of two satellites, Sich-2-1 and Sich 2-2, and the experimental development of the Sich-2M satellite.

The ways of using images from Ukrainian Earth remote sensing satellites considered in this paper may be used in planning the operation of the Sich-2-1, the Sich-2-2, and the Sich-2M satellites in such a way as to allow Ukraine to enter the international scene, for example, though cooperation with international systems, such as GEOSS, DMC, COPERNICUS, etc.

Keywords: Earth remote sensing, satellite, space image, trends in space system development, international cooperation.

1. Online space monitoring of the Earth (in Russian) URL: http://mapexpert.com.ua/index_ru.php?id= $74 \&$ table $=$ news (last accessed on January 15, 2019).

2. Disaster Monitoring Constellation: watchful eyes in the heavens. MEMBRANA Project (in Russian) . URL: http://www.membrana.ru/particle/321 (last accessed on January 15, 2019).

3. Earth remote sensing satellite. TopSat (in Russian). URL: https://ecoruspace.me/TopSat.html (last accessed on January 15, 2019).

4. A constellation of DMC-3 new-generation small satellites for Earth remote sensing have been orbited successfully (in Russian). URL:https://sovzond.ru/press-center/news/market/2557 (last accessed on January 15, 2019)

5. Europe. Funding of the GMES Project (in Russian). Aviation Week and Space Technology. 2003. 8/XII. V. 1, No. 23. Pp. $38-40$.

6. GEOSS - Group on Earth Observations. URL: https://www.earthobservations.org/geoss.php (last accessed on January 15,2019 )

7. Umbrella document adopted by IGOS Partners at their second meeting in November 1998, and up-dated as required. URL: Integrated Global Observing Strategy. URL: http://www.un.org/earthwatch/about/ docs/igosstr.htm (last accessed on January 15, 2019)

8. President of Brazil's visit to the International Telecommunication Union (in Russian). ITU News Magazine. July-August 2009. URL: http://www.itu.int/net/itunews/issues/2009/06/13-ru.aspx (last accessed on January 15, 2019) 